\title{
R\&D and Economic Performance: Simultaneous Estimates of the Reciprocal Effects for Africa and Other Regions
}

\author{
Solomon Abayomi OLAKOJO, Ph.D ${ }^{1}$ \\ Department of Economics University of Ibadan, Ibadan, Nigeria. \\ Email: solomonolakojo@gmail.com
}

\begin{abstract}
Research and Development (R\&D) expenditure in most African countries is low. This study investigates the impact of R\&D on economic performance of 23 African countries between 1995 and 2014. It also compares selected Africa countries with 25 countries across South America, Asia and Organization of Economic Co-operation and Development (OECD). A new growth model, incorporating R\&D, was estimated with two-stage least squares (2SLS) fixed and random effect panel regression. The results show that R\&D enhances real output in Africa with elasticity of $0.01 \%$. Other regressors such as investment, savings and labour also enhance output performance with elasticities of $0.39 \%, 0.05 \%$, and $0.35 \%$, respectively. There were variations across estimations involving other regions. African countries need to provide adequate funding for research and mobilize domestic resources through savings and investment to become growth pillars.
\end{abstract}

Key words: Africa, R\&D investment, economic performance.

JEL codes: O32, O47

\section{Introduction}

The development of new products and processes is clearly a major factor behind economic growth in the developed economies [1]. In other words, developed economies today emerged from agrarian economies into industrial nations as a result of serious investment in research and development (R\&D). In Africa, investment in R\&D is very low. For instance, available statistics from the World Bank's World Development Indicators [2] suggest that R\&D expenditure (\% of gross domestic product (GDP)) in SubSahara Africa (SSA) recorded $0.57 \%$ in 2007, while the world average stood at $2.0 \%$. In the developed countries such as high income non-OECD and OECD, it recorded $0.89 \%$ and $2.37 \%$, respectively in the same period. This implies that African investment in R\&D is about four times less than the world average and what obtained in developed countries, while the continent falls short of the UNESCO benchmark of 1\% R\&D expenditure in GDP. Besides, Researchers in R\&D (per million people) are less than 100 in Africa (with heterogeneity across the countries, nevertheless), while the world average, high income non-OECD and OECD average stood at 1283.90, 2983.41 and 3322.56, respectively in 2010 [2].

R\&D and economic growth are basically two sides of the same coin. A bi-directional relationship: R\&D facilitates growth, and growth also facilitates R\&D. While the low level of growth serves as a constraint to investment in R\&D, a country with low level of investment in R\&D should expect slow growth. That is, low investment in R\&D leads to slow growth and slow growth further leads to low investment in $\mathrm{R} \& \mathrm{D}$, making the undesired circle of slow growth to continue. Meanwhile, it is important to understand the essence of $R \& D$ as a source of economic growth. Empirical evidences such as Clark and Griliches [3] and Kim [4] support that R\&D leads to improved productivity at micro and macro level, respectively. However, most empirical studies focused on developed countries without adequate attention to what obtains in developing countries, while the potential reciprocal relationship between R\&D and economic growth is lacking in Africa context.

\footnotetext{
${ }^{*}$ The Author acknowledges African Economic Research Consortium (AERC) and Development Research Department, African Development Bank (AfDB) for the research fellowship opportunity to carry out this study. The usual disclaimer applies.
} 
Based on the established association between R\&D and economic growth as well as the observed gaps in empirical literature, this study examines the relationship between R\&D and economic growth in Africa, focusing on the period of relative rapid growth between 1995 and 2014. Specifically, it seeks to compare some emerging economies in South America (such as Brazil, Agentina, Venezuela and Trinidad and Tobago), OECD economies (such as USA, Canada, United Kingdom, France, Germany, Denmark and Japan) and Asian economies (such as China, Indonesia, Malaysia, and Thailand) with Africa countries in order to learn some lessons.

The rest of the paper is organised as follows: apart from the introductory section, section two is on the literature review focusing on theories, method and evidence. Section three presents theoretical framework and methodology, while the results are presented in section four. Section five concludes the study with policy recommendation.

\section{$2 \quad$ Literature Review}

Growth theories have explained several factors responsible for growth differences across countries. In the neoclassical growth models such as Solow growth model (a model of capital accumulation in a pure production economy), growth differences across countries are determined by differences in growth rate of capital accumulation derivable from savings. The augmented Solow growth model focuses on factors causing growth drag across countries. It concludes that growth drag is increasing in population growth and natural resources depletion and decreasing in share of capita stock in the production process. However, the neoclassical growth models failed to model knowledge assuming that it is exogenously determined. This is acknowledged by the new or endogenous growth theory given that knowledge is the main driver of technology that explains growth in the neoclassical world.

Endogenous growth theory holds that growth cannot be exclusively explained by physical resources but investment in human capital, innovation, and knowledge are significant drivers of economic growth. Hence, most endogenous growth models replaced exogenous technological progress with endogenous growth of knowledge and assumed dynamics of both physical and human capital as well as knowledge dynamics. For instance, Otani and Villanueva (1989 cited in Otani and Villanuev [5]) based on the contemporary development, especially among the developing economies, presented a theoretical growth model. This model emphasized the role of structural parameters of macroeconomic relationships including the savings-investment-growth linkage, expenditures to improve human capital, and the dynamics of external debt on the long run growth.

The research and development models hold that economic growth is generated by investment in research and development. The model assumes that there are two sectors: Goods and R\&D, while the society is assumed to allocate its resources between the two sectors. The expectation is that an increase in the fraction of the economy's resources devoted to technological progress through R\&D increases growth in the long run. In term of the model's dynamics, a limited contribution of the additional knowledge to the production of new knowledge will make growth unsustainable. However, if the production of the new knowledge rises more proportionately with the existing stock of knowledge, increase in labour force in $R \& D$ causes the growth rate to exceed what it would have been, leading to ever increasing growth. Meanwhile, if the existing knowledge is just productive enough in generating new knowledge, there is no adjustment toward a balance growth path and the economy immediately exhibits steady state growth. In sum, the fraction of labour force devoted to R\&D affects the long run growth rate of the economy [6].

On the empirical and methodology front, few studies have investigated the relationship between economic performance and R\&D investment, mostly among developed countries. Hence, the review of the previous studies will be polarized into developed and developing countries studies.

\subsection{Developed Countries Studies}

Among the studies in the developed countries, Sylwester [7] examines the association between R\&D and the growth rate of output per capita among 20 OECD countries utilizing multivariate regression technique. The basic finding is that, over the whole sample, there is no association between R\&D and economic growth. When considering only G-7 countries however, there is a positive association. Related 
to this, Pessoa (2010) examines the relationship between R\&D outlays and economic growth in 28 OECD countries between 1995 and 2005 using a fitted regression model to estimate the ideas-driven growth mode with free entry and exit conditions. The results show a weak impact of innovation policy on aggregate productivity. Only increase in R\&D intensity improves growth. On the contrary, Guellec and he de la Potterie [8], Ulku [9], Falk [10], Pessoa [11] and Gumus and Celikay [12] find a positive association. For instance, Guellec and he de la Potterie [8] analyse the contribution of technical change to total factor productivity of industry growth among 16 OECD countries between 1980 and 1998. Using simple Cobb-Douglas production frame work estimated with error correction mechanism, the study finds that technology is relevant to economic growth. Further, using system GMM to estimated augmented Solow growth model, Falk [10] investigates impact of investment in R\&D on long-term economic growth among OECD economies between 1970 and 2004. The study finds that R\&D investment in the hightech sector has strong positive effects on GDP per capita and GDP per hour worked in the long term. Similarly, Ulku [9] investigates the relationship between R\&D and growth in 20 OECD and 10 NonOECD countries between 1981 and 1997 using R\&D based growth model of Romer. The basic findings, utilizing Generalized method of moment (GMM) Panel data techniques, show a positive relationship between per capita GDP and innovation in both OECD and non-OECD countries, while the effect of R\&D stock on innovation is significant only in the OECD countries with large markets.

In some other developed countries studies besides OECD studies, Goel, Payne and Ram [13] investigate R\&D-growth relationship in the US between 1953 and 2000. The study utilises bound testing approach and finds larger role of federal $R \& D$ relative to non-federal $R \& D$ in growth, and a stronger role of defense R\&D than of non-defense (federal) R\&D. Estrada and Montero [13] examine impact of R\&D investment on long run growth in six developed countries including Spain between 1970 and 2006. The study uses new growth theory as a framework estimated with structural vector autoregressive (SVAR) model. The summary of findings is that R\&D shocks have a positive impact on economic activity, but a heterogeneous effect on prices. Kim [15] focuses on the impact of R\&D stock on economic growth in Korea between 1976 and 2009. Using co-integration analysis, it is indicated that public and private R\&D stocks account for economic growth of about $16 \%$ and $19 \%$, respectively. Křístková [16] quantifies the impact of R\&D activity on the long-term economic growth in Czech Republic between 2000 and 2009. With the use of CGE model with R\&D investment and knowledge accumulation, the study finds that Knowledge accumulation contributes to higher economic growth and investment in capital goods is more efficient in achieving higher economic growth. Among Members of European Union between 1987 and 2008, Santosa and Catalao-Lopes [17] investigate the causal relationship linking R\&D and growth using cointegrtation and granger causality test. The study finds a causal relationship from growth to R\&D, and can only be proven for France and Spain, whereas the inverse causality only seems to exist for The Netherlands. Also, in Turkey between 1996 and 2013, Bozkurt [18] investigates the longrun relationship between $R \& D$ expenditure and economic growth utilizing Johansen co-integration and the vector error correction models. The study shows that growth rate of GDP will increase by $0.3 \%$ if R\&D shares in the GDP increase by $1 \%$.

\subsection{Mix of Developed and Developing Countries Studies}

Some studies estimated the relationship between R\&D and economic growth sampling both developed and developing countries. In this category, Bravo-Ortega and Marin [19] studied the relationship between R\&D and productivity in 65 countries between 1965 and 2005. The study utilized instrumental variables panel data technique. The basic finding is that increase in $R \& D$ per capita generates increase in TFP in the long-run. Similarly, Gumus and Celikay [12] estimated the relationship between R\&D and economic growth among 52 developed and developing countries between 1996 and 2010, and employed dynamic panel data model. The study shows that R\&D expenditure has positive impact of growth among all the economies sampled in the long run but the effect of developing countries is weak in the short run, only strong in the long run.

\subsection{Studies on Developing Economies}

Very few studies exist on developing economies relating to R\&D and economic growth. Among the studies with developing countries as focus, Samimi and Alerasoul [20] estimate the impact of R\&D on 
economic growth sampling 30 developing countries between 2000 and 2006. The study used panel regression model with the basic result of no significant positive impact of $\mathrm{R} \& \mathrm{D}$ on economic growth. This is attributed to low and inefficient allocation of R\&D expenditure in the sampled countries. In a related study, but contrary to the findings of Samimi and Alerasoul [20], Gocer (2013, cited by Gumus and Celikay [12]) finds a positive relationship between R\&D expenditure and economic growth in 11 developing Asian countries for the period of 1996 to 2006. Specifically, 1\% increase in R\&D expenditure increases modern technology goods exports by $6.5 \%$, information-communication technology exports by $0.6 \%$ and economic growth by $0.43 \%$.

From the review above, it is obvious that most of these studies do not focus on Africa. This study seeks to focus on Africa, while accounting for endogeniety between R\&D and GDP. The concise summary of these studies and others is presented in Table A1.

\section{Method and Materials}

The framework for the study is derived from endogenous R\&D growth model which assumes two sectors: the good sector and the R\&D sector. While good and R\&D sectors rely on capital and labour, R\&D sector produces new technology necessary for the survival of good sector. Both the R\&D and goods sectors are assumed to be generalized Cobb-Douglass production function. The good sector production function takes the form:

$$
Y(t)=[(1-a k) K(t)]^{\alpha}[A(t)(1-a l) L(t)]^{1-\alpha}
$$

where $\mathrm{Y}(\mathrm{t})$ is output of goods, $(1-a k)$ is the proposition of capital employed, $\mathrm{K}(\mathrm{t})$ is the capital employed, $\mathrm{A}(\mathrm{t}) \mathrm{L}(\mathrm{t})$ is labour augmenting technological progress (effective labour), and 1-al is the proportion of effective labour employed in good sector. $a$ and 1- $a$ are the share of capital and labour in producing a unit of output in good sector.

The production of new knowledge function in the R\&D sector is stated as:

$$
\dot{A}(t)=[(a k) K(t)]^{\beta}[(a l) L(t)]^{\lambda} A(t)^{\theta}
$$

where $A(t)$ is production of new knowledge, $a k$ is the proposition of capital employed, $\mathrm{K}(\mathrm{t})$ is the capital employed, $\mathrm{L}(\mathrm{t})$ is labour employed and $a l$ is the proportion of labour employed in R\&D sector. B and $\lambda$ are the share of capital and labour in producing an additional knowledge in R\&D sector.

While production function in goods sector exhibits constant return to scale, production in knowledge sector is not necessarily restricted to this. This is because $\theta$ measuring the effect of existing knowledge on success of $R \& D$ sector may be greater or less than 1 , indicating that the past knowledge is greater and less than the present knowledge, respectively. In the former, the future discoveries become easier but do not give enough room for further discoveries, while there is enough room for more discoveries in the latter. This is a condition that ensures convergence and is related to the neoclassical growth theory idea that marginal product of capital tends to infinity when capital tends to zero and vice versa. This can be demonstrated by dividing equation (2) by $\mathrm{A}(\mathrm{t})$, linearizing and differentiating with respect to time bearing in mind that the growth of growth rate of knowledge (that is, $\dot{g}_{A}$ ) is zero on the BGP. These yield:

$$
g_{A}^{*}=\frac{\beta g_{K}+\lambda n}{1-\theta}
$$

where $g_{A}^{*}, g_{K}$ and $\lambda n$ are the growth of knowledge, capital and labour, respectively.

Recall that:

$$
\frac{\dot{A}(t)}{A(t)}=g_{A}=[(a k) K(t)]^{\beta}[(a l) L(t)]^{\lambda} A(t)^{\theta-1}
$$

Equating equations (3) and (4) and organizing yields:

$$
A(t)^{\theta-1}=\frac{\lambda n+\beta g_{K}}{(1-\theta)[(a k) K(t)]^{\beta}[(a l) L(t)]^{\lambda}}
$$




$$
A(t)=\left[\frac{(1-\theta)[(a k) K(t)]^{\beta}[(a l) L(t)]^{\lambda}}{\lambda n+\beta g_{K}}\right]^{\frac{1}{1-\theta}}
$$

Equation (6) implies that the determinants of R\&D productivity (that is, $A(t)$ ) are the proportion of labour and capital employed as well as positive technology shocks and not necessarily population growth and the stock of capital an economy possesses.

Substituting equation (6) in (1) gives:

$$
Y(t)=[(1-a k) K(t)]^{\alpha}\left[\left[\frac{(1-\theta)[(a k) K(t)]^{\beta}[(a l) L(t)]^{\lambda}}{\lambda n+\beta g_{K}}\right]^{\frac{1}{1-\theta}}(1-a l) L(t)\right]^{1-\alpha}
$$

This implies that output of goods sector is a function not only the input resources employed in goods sector but also the inputs employ in R\&D sector.

Meanwhile, the interest is on the relationship between R\&D and economic growth. Hence, equation (7) is expressed as:

$$
Y(t)=[(1-a k) K(t)]^{\alpha}\left[\frac{(1-\theta)[(a k) K(t)]^{\beta}[(a l) L(t)]^{\lambda}}{\lambda n+\beta g_{K}}\right]^{\frac{1-\alpha}{1-\theta}}[(1-a l) L(t)]^{1-\alpha}
$$

Re-organizing equation (8) yields:

$$
Y(t)=K(t)^{\frac{\alpha(1-\theta)+\beta(1-\alpha)}{1-\theta}} L(t)^{\frac{(1-\alpha)(1-\theta)+\lambda(1-\alpha)}{1-\theta}}(1-a k)^{\alpha}(1-\theta)^{\frac{1-\alpha}{1-\theta}}(a k)^{\frac{\beta(1-\alpha)}{1-\theta}}(a l)^{\frac{\lambda(1-\alpha)}{1-\theta}}\left(\lambda n+\beta g_{K}\right)^{-\frac{1-\alpha}{1-\theta}}(1-a l)^{1-\alpha}
$$

Linearising equation (9) and differentiating with respect to time gives:

$$
\frac{\dot{Y(t)}}{Y(t)}=\frac{\alpha(1-\theta)+\beta(1-\alpha)}{1-\theta} \frac{\dot{K(t)}}{K(t)}+\frac{(1-\alpha)(1-\theta)+\lambda(1-\alpha)}{1-\theta} \frac{\dot{L(t)}}{L(t)}
$$

where $\frac{\dot{Y(t)}}{Y(t)}=g_{y}$ is the growth rate of output, $\frac{\dot{K(t)}}{K(t)}=g_{k}$ is the growth rate of capital stock and $\frac{\dot{L(t)}}{L(t)}=n$ is the growth rate of labour.

The dynamics of capital stock and labour is given, respectively as;

$$
\begin{aligned}
& \dot{K(t)}=s Y(t)-\rho K(t) ; \frac{\dot{K(t)}}{K(t)}=\frac{s Y(t)}{K(t)}-\rho \\
& \dot{L(t)}=n(L(t)) ; \frac{\dot{L(t)}}{L(t)}=n
\end{aligned}
$$

where $s$ is the propotion of income that is saved and $\rho$ is the rate of existing capital depreciation. Hence, if the proportion of income saved is higher than the rate of capital depreciation the growth of capital stock will be positive and vice versa.

Subtituting the expressions in equations (11) and (12) in equation (10) gives:

$$
g_{y}=\frac{\alpha(1-\theta)+\beta(1-\alpha)}{1-\theta}\left(\frac{s Y(t)}{K(t)}-\rho\right)+\frac{(1-\alpha)(1-\theta)+\lambda(1-\alpha)}{1-\theta} n
$$

Note that $\mathrm{Y}(\mathrm{t}) / \mathrm{K}(\mathrm{t})$ is the average product of capital (that is, B henceforth) and on the balance growth path all variables growth at the same rate, thus growth rate of output equals growth rate of labour. This implies that: 


$$
\begin{gathered}
g_{y}^{*}=\frac{\frac{\alpha(1-\theta)+\beta(1-\alpha)}{1-\theta}(s(B)-\rho)}{1-\frac{(1-\alpha)(1-\theta)+\lambda(1-\alpha)}{1-\theta}}=\frac{\alpha(1-\theta)+\beta(1-\alpha)}{(1-\theta)-(1-\alpha)(1-\theta)+\lambda(1-\alpha)}(s(B)-\rho) \\
g_{y}^{*}=\frac{\alpha(1-\theta)+\beta(1-\alpha)}{(1-\theta)+\alpha+\lambda(1-\alpha)}(s(B)-\rho)
\end{gathered}
$$

Assuming that the existing knowledge is just productive enough in generating new knowledge, that is, $\theta=1$, equation (13) becomes:

$$
g_{y}^{*}=\frac{\beta(1-\alpha)}{\alpha+\lambda(1-\alpha)}(s(B)-\rho)
$$

Equation (14) implies that higher share of labour devoted to good production (1- $\alpha$ ) and share of capital devoted to the production of new knowledge $(\beta)$ must be associated with higher share of capital in good sector and labour devoted to the production of new knowledge $(\lambda)$, while saving rate must balance the rate of capital depreciation, otherwise the long run growth will not be sustained.

\subsection{Model Specification}

The reduced-form equation to be estimated for the empirical analysis is simplified as follows:

$$
g_{y}=f\left(L, S, I_{R \& D}, I\right)
$$

where $g_{y}$ is $\log$ of real output; $\mathrm{L}$ is $\log$ of labour force; $\mathrm{S}$ is $\log$ of gross national savings, $\mathrm{I}_{\mathrm{R} \& \mathrm{D}}$ is $\log$ of high technologv manufacture export (high-technology manufacture exports are products with high R\&D intensity, such as in aerospace, computers, pharmaceuticals, scientific instruments, and electrical machinery (WDI, [2]). This is a proxy for expenditure and investment in R\&D. Using this as a proxy for investment in $R \& D$ is iustified because similar causality between $R \& D$ investment and Economic growth (as previously indicated) also exits between trade and economic growth. That is, while a country export may be determined by its output level, output level may also determine the level of export intensity); I is $\log$ of gross fixed capital formation, which a proxy for changes in capital stock. Since no meaningful information is available on the rate of depreciation of the capital stock as well as no adequate information on capital and labour employed in $R \& D$ and good sector, these variables are excluded from the growth equation. The expected signs with respect to all the explanatory variables are positive.

\subsection{Estimation Techniques}

In terms of sequencing, the study first confirms the causality between $\mathrm{R} \& \mathrm{D}$ and economic growth by employing bivariate PVAR technique, which treats both variables as endogenous. However, unlike tradition VAR approach which assumes parameters homogeneity, panel-data approach allows for unobserved individual heterogeneity by imposing a restriction on parameters to capture "individual heterogeneity" in the levels of the variables by introducing fixed effects, denoted by $f_{i(j)}$ in the equations:

$$
\begin{aligned}
& R G D P_{i t}=\lambda_{1, t}+\beta_{1 i} R G D P_{t-1}+\alpha_{1 j} R \& D_{t-1}+f_{i}+\varepsilon_{i, t} \\
& R \& D_{j t}=\lambda_{2, t}+\beta_{2 i} R G D P_{t-1}+\alpha_{2, j} R \& D_{t-1}+f_{j}+\varepsilon_{j, t}
\end{aligned}
$$

where $\varepsilon_{\mathrm{it}}$ and $\varepsilon_{\mathrm{j}, \mathrm{t}}$ are idiosyncratic errors. With respect to this system, there is one-way causality running from real Gross domestic Product (RGDP) to R\&D if in (16) $\alpha_{1, j}$ is zero but in (17) $\beta_{2, j}$ is nonzero, there is one-way causality from R\&D to RGDP if in (17) $\beta_{2, j}$ is zero but in (16) $\alpha_{1, j}$ is non-zero, there is two-way causality between RGDP and R\&D expenditure if neither $\alpha_{1, j}$ nor $\beta_{2, j}$ is zero, and there is no causality if $\alpha_{1, j}$ and $\beta_{2, j}$ are zero.

Meanwhile, the fixed effects are likely to be correlated with the regressors due to lags of the dependent variables; hence, the mean-differencing procedure commonly used to eliminate fixed effects would create biased coefficients. Hence, in order to avoid this problem this study uses forward meandifferencing, also referred to as the 'Helmert procedure' (see Love and Ziccino, [21]). This procedure 
removes only the forward mean, that is, the mean of all the future observations available for each country pair-year. This transformation preserves the orthogonality between transformed variables and lagged regressors, hence the lagged regressors can be used as instruments and estimate the coefficients by system Generalized Method of Moment (GMM).

Subsequently, the study accounts for the above endogeniety using instrumental variable Two Stage Least Squares (2SLS) method. This is necessary to purge RGDP of its endogeneity and make R\&D and other variables truly exogenous. The general specification of the relationship between R\&D and RGDP is given as;

$$
g_{y_{j t}}=\alpha I_{R \& D j t}+\beta \prod_{j t}+\varepsilon_{j t}
$$

where $g_{y j t}$ is the endogenous variable and $I_{R \& D j t}$ as well as other variables such as investment and savings are also a potential endogenous variable. This is problematic and there is a need to deal with it. $\Pi_{j t}$ is the number of exogenous variables that are being considered, while $\varepsilon_{j}$ is the error term.

To account for possible heterogeneity across cross-sectional observations the study uses either fixed or random effect, depending on the F-test and Hausman test outcomes. In terms of instruments, one year lag of explanatory variable (log of real output) and suspected endogenous variable (log of manufacture export dominated by R\&D investment) are used. Since the dependent variables are assumed to be truly endogenous, it is straight forward to think of using a year lag as instruments; these are assumed to be correlated with dependent variables and uncorrelated with residuals.

To choose between the models above, the study relies on the Hausman specification test and the hypothesis tested are:

$H_{0}$ : No significant difference between 2SLS fixed effect Vs 2SLS random effect models

$H_{1}$ : Significant difference in the two models (use 2SLS fixed effect)

\subsection{Data and Sample}

The data for the study is sourced mainly from World Bank's World Development Indicators [2], measured in US dollars. While high-technology manufacture exports and gross domestic savings are measured in nominal term, GDP and gross fixed capital formation are measured in real term. Total labour force includes both the employed as well as the unemployed and comprises people aged 15 and older who meet the International Labour Organization definition of the economically active population. The choice of countries was determined essentially by the availability of data. The number of sample countries was 48 with 23 African countries; 4 South American countries; 16 OECD economies; and 5 Asian economies. The full list of these countries is indicated in the appendix (Table A2).

\section{$4 \quad$ Results and Discussion}

\subsection{Descriptive Analysis of Variables}

A look at the nature of variables across the selected regions shows that Africa is the least in terms of R\&D investment indicated by low level of export of high technology manufacture goods. While the value of high technology manufactures export goods averages about $\$ 0.1$ billion between 1995 and 2014 that of South America, OECD and Asia recorded $\$ 1.9, \$ 48.3$ and $\$ 57.2$ billion, respectively within the same period (Table 1). Likewise, the African average real GDP value of $\$ 32$ billion is the least representing about $9 \%, 1.7 \%$, and $4.1 \%$ of that of South America, OECD and Asia (Table 1). Africa also indicates the lowest values in terms of domestic savings and investment as well as labour force compared with other regions. Relating R\&D investment to the sampled economies' real GDP, African countries recorded about 0.3\%, while South America, OECD and Asian counties recorded approximately 0.6\%, 2.6\% and $7.3 \%$, respectively. The coefficient of variations (cv)-a measure of dispersion of probability distribution of the variables shows that the variables exhibit high variability across panels. 
Table 1. Descriptive analysis

\begin{tabular}{|c|c|c|c|c|c|}
\hline \multirow{3}{*}{ statistics } & \multicolumn{4}{|c|}{ Africa } & \multirow{3}{*}{ labor } \\
\hline & htexp & $\operatorname{rgdp}$ & $\mathrm{gds}$ & rgfcf & \\
\hline & (Billion USD) & (Billion USD) & (Billion USD) & (Billion USD) & \\
\hline mean & 0.1 & 32 & 8 & 6.23 & $8,958,449$ \\
\hline $\mathrm{sd}$ & 0.33 & 57.9 & 19 & 11.1 & $9,577,575$ \\
\hline \multirow[t]{2}{*}{$\mathrm{cv}$} & 3.4 & 1.8 & 2.4 & 1.8 & 1.1 \\
\hline & \multicolumn{5}{|c|}{ South America } \\
\hline mean & 1.92 & 325 & 92.2 & 64.2 & $30,400,000$ \\
\hline $\mathrm{sd}$ & 2.95 & 356 & 117 & 71.5 & $36,800,000$ \\
\hline \multirow[t]{2}{*}{$\mathrm{cV}$} & 1.5 & 1.1 & 1.3 & 1.1 & 1.2 \\
\hline & \multicolumn{5}{|c|}{ OECD } \\
\hline mean & 48.3 & 1850 & 390 & 397 & $26,800,000$ \\
\hline $\mathrm{sd}$ & 52.4 & 2980 & 544 & 627 & $36,400,000$ \\
\hline \multirow[t]{2}{*}{$\mathrm{cV}$} & 1.1 & 1.6 & 1.4 & 1.6 & 1.4 \\
\hline & \multicolumn{5}{|c|}{ Asia } \\
\hline mean & 57.2 & 782 & 421 & 283 & $268,000,000$ \\
\hline $\mathrm{sd}$ & 111 & 1040 & 865 & 465 & $288,000,000$ \\
\hline \multirow[t]{2}{*}{$\mathrm{cv}$} & 1.9 & 1.3 & 2.1 & 1.6 & 1.1 \\
\hline & \multicolumn{5}{|c|}{ All Sample } \\
\hline mean & 23.4 & 741 & 186 & 172 & $43,700,000$ \\
\hline $\mathrm{sd}$ & 54.2 & 1930 & 461 & 433 & $123,000,000$ \\
\hline $\mathrm{cV}$ & 2.3 & 2.6 & 2.5 & 2.5 & 2.8 \\
\hline
\end{tabular}

Source: Computed

Note: htexp is high technology manufacture exports, rgdp is real gross domestic product, gds is gross domestic savings and rgfcf is real gross fixed capital formation. Sd is standard deviation and cv is coefficient of variations.

\subsection{Bivariate Causality between RGDP and R\&D Expenditure}

The results of the bivariate Panel Vector Autoregressive (PVAR) estimates indicate bidirectional causality between RGDP and R\&D expenditure in all sample estimations (equations 19 and 20). However, the coefficients of the PVAR indicate that the causality is stronger from RGDP to R\&D expenditure than vice versa. That is, a greater level of RGDP is required for higher investment in R\&D. This is intuitively appealing since R\&D expenditure can be claimed to be a component of gross output invest in $R \& D$ to produce further output in more efficient ways. In the case of Africa, weaker bidirectional causality is observed with a stronger causality running from RGDP to R\&D expenditure and less when considering the reverse (equations 21 and 22). Hence, the two-way causality between the two corroborates some of the theoretical arguments.

\section{All Sample Estimation}

$$
\begin{aligned}
R G D P_{i t}= & 0.876 R G D P_{t-1}+0.007 R \& D_{t-1} \\
& (99.27) * * * \\
R \& D_{t}= & 0.850 R G D P_{t-1}+0.400 R \& D_{t-1} \\
& (4.82)^{* * *}
\end{aligned}
$$

\section{Africa Estimation}

$$
\begin{aligned}
R G D P_{i t}= & 0.885 R G D P_{t-1}+0.004 R \& D_{t-1} \\
& (102.317) * * * \\
R \& D_{t}= & 1.357 R G D P_{t-1}+0.306 R \& D_{t-1} \\
& (4.446) * * *
\end{aligned}
$$

Note: t_GMM are in the parentheses. ${ }^{*},{ }^{* *},{ }^{* *}$ imply significant at 10\%,5\% and 1\%, respectively. 1-lag VAR is estimated by GMM 


\subsection{Estimates of RGDP Elasticities}

The estimated models of growth elasticities in Table 2 show that investment in R\&D improves growth, except in the case of South American countries. However, the impacts are inelastic and vary from one region to another. These corroborate the previous PVAR results. For instance, the response of GDP to R\&D investment is quite weak among African economies unlike what obtained in Asian and OECD countries. The implication of the results, related to theory, is that investment in $R \& D$ is still relatively low compared to the sizes of real gross outputs of the selected countries (Table 2), which is a condition that ensures convergence. That is, marginal product of $R \& D$ investment tends to infinity when $R \& D$ investment tends to zero and vice versa. Investment in $R \& D$ is not significantly driven growth in the case of South American countries, despite the fact that the average investment in R\&D is greater than those of African countries (see Table 1). One of the explanations that could be offered for this is that there have been divestments in $R \& D$ indicated by recent drop in high technology intensive manufacture exports [2]. This is specifically noticed with Brazil and Venezuela.

Domestic savings is an important driver of growth across the regions. However, the elasticity is smallest for the African countries followed by the OECD. The explanation for this is that savings is very low in Africa to ensure desired growth, while savings among the OECD is huge such that the marginal effect of additional savings does not really drive growth. Although there is significant effect of investment on growth but leakage is observed among the South American countries where savings are not channelled to growth through investment as used in this study. It is worth nothing that the type of investment used in this study may account for this. In this study, gross domestic fixed investment (such as investment in land improvements, plant, machinery, and equipment purchases; and the construction of roads, railways, schools, offices, hospitals, private residential dwellings, and commercial and industrial buildings) was used.

Table 2. Estimates of Growth Elasticities

\begin{tabular}{l|l|l|l|l|l}
\hline & Africa & South America & OECD & Asia & All sample \\
\hline & $\begin{array}{l}\text { IV 2SLS } \\
\text { RE }\end{array}$ & $\begin{array}{l}\text { IV 2SLS } \\
\text { FE }\end{array}$ & $\begin{array}{l}\text { IV 2SLS } \\
\text { FE }\end{array}$ & $\begin{array}{l}\text { IV 2SLS } \\
\text { FE }\end{array}$ & $\begin{array}{l}\text { IV 2SLS } \\
\text { RE }\end{array}$ \\
\hline loghtexp & $0.011(2.92)^{* * *}$ & $0.001(0.11)$ & $0.053(4.83)^{* * *}$ & $0.162(10.27)^{* * *}$ & $0.022(5.25)^{* * *}$ \\
\hline loggds & $0.054(5.43)^{* * *}$ & $0.295(8.78)^{* * *}$ & $0.058(2.76)^{* * *}$ & $0.123(3.85)^{* * *}$ & $0.090(8.47)^{* * *}$ \\
\hline loggfcf & $0.390(16.48)^{* * *}$ & $-0.043(-0.95)$ & $0.259(7.80)^{* * *}$ & $0.221(4.86)^{* * *}$ & $0.479(23.94)^{* * *}$ \\
\hline loglabor & $0.339(7.28)^{* * *}$ & $0.415(2.26)^{* *}$ & $0.956(11.25)^{* * *}$ & $0.761(6.71)^{* * *}$ & $0.287(18.10)^{* * *}$ \\
\hline cons & $8.208(16.57)^{* * *}$ & $12.833(5.11)^{* * *}$ & $2.300(2.10)^{* *}$ & $0.074(0.01)$ & $6.684(18.10)^{* * *}$ \\
\hline Statistics & & & & & \\
\hline $\mathrm{R}^{2}$ & 0.90 & 0.99 & 0.93 & 0.98 & 0.96 \\
\hline Rho & 0.91 & 0.97 & 0.99 & 0.99 & 0.87 \\
\hline F-test (U_i=0) & $189.71^{* * *}$ & $8.49^{* * *}$ & $144.64^{* * *}$ & $41.5^{* * *}$ & $143.69^{* * *}$ \\
\hline Wald $\mathrm{X}^{2}(4)$ & $2571.99^{* * *}$ & $6240^{* * *}$ & $8450^{* * *}$ & $2230^{* * *}$ & $5435.08^{* * *}$ \\
\hline Hausman $\mathrm{X}^{2}$ & $11.24^{* *}$ & $41.79^{* * *}$ & 7.46 & $41.41^{* * *}$ & $1031.08^{* * *}$ \\
\hline Observations & 331 & 66 & 288 & 90 & 774 \\
\hline Number of groups & 23 & 4 & 16 & 5 & 48 \\
\hline
\end{tabular}

Source: Computed

Note: ** and *** imply significance at $5 \%$ and $1 \%$, respectively. Note: htexp is high technology manufacture exports, gds is gross domestic savings and rgfcf is real gross fixed capital formation and labour is total labour force.

The labour coefficients also have important consequences. It is noticed that growth elasticity of labour among African countries is the smallest-a situation in which $1 \%$ increase in total labour increases growth by only $0.3 \%$. This implies high level of unemployment among African economies compared to other regions. In other words, since total labour includes both the employed and unemployed, weak impact of labour force on output implies high level of unemployed factor, especially in Africa where production could be said to be labour intensive. Similarly, it is noticed that output-labour elasticity among the 
OECD economies is the highest-where output goes hand-in-hand with labour. This is followed by Asian countries- where $1 \%$ increase in labour increases output by about $0.8 \%$. South American economies shared similar characteristics with Africa. Overall, R\&D influence on real GDP is about $0.02 \%$, while the major influence gross fixed capital formation.

These findings are in line with theoretical debate regarding relationship between R\&D and economic growth. Across the estimations, increase in the fraction of the economy's resources devoted to technological progress through R\&D increases growth. In growth theory, the results imply that the effect of existing knowledge on success of $R \& D$ sector may be less than 1 , indicating that the past knowledge is less than the present knowledge. That is, there is enough room for more discoveries to improve growth among the selected economies. This is a condition that ensures convergence and is related to the neoclassical growth theory idea that marginal product of capital tends to infinity when capital tends to zero and vice versa.

In terms of model selection and adequacy, the selection of models, either fixed or random effect, was based on outcome of F-test and Hausman test. That is, the first step was estimations of panel regression accounting for heterogeneity across cross sectional observations using F-test from the fixed effect estimates. The second step involves testing whether the heterogeneity was actually fixed or random using Hausman test. Consequently, the rhos values across the estimations show that over $90 \%$ of variances across cross-sectional observations were due to individual effects. Besides, the $\mathrm{R}^{2}$ and wald chisquare shows, respectively that the explanatory variables do not explain less than $90 \%$ of the variations in the output elasticity and overall model is adequate. However, the significance of constant term, except in the case of Asian countries, shows that some variables explaining output elasticity are missing, while the number of factors accounting for output has been reduced to a small number of key variables. Despite these shortcomings, the empirical results are informative.

\section{Conclusion}

This study investigates relationship between R\&D and real GDP among 48 countries grouped into 23 African countries, 4 economies from South America, 5 from Asia and 16 from Organization of Economic Co-operation and Development (OECD). The study covered the period of 1995 to 2014. This is partly based on data availability and it is also regarded the period of rapid growth among African countries. A new growth model incorporating R\&D was estimated with two-stage least squares (2SLS) fixed and random effect panel regression that account for endogeniety between $R \& D$ and output, while panel vector autoregressive (PVAR) causality test was performed to confirm endogeniety between R\&D investment and real GDP.

The basic finding of the study is that there is weak bi-directional causality between R\&D investment and real output. The causation is stronger from real GDP to R\&D investment. Also, the 2SLS results show that R\&D enhances real output in Africa with elasticity of 0.01 . Other regressors such as investment, savings and labour also enhance output performance with elasticities of $0.39,0.05$, and 0.35 , respectively. The other regions' results are similar to the selected African countries, except among South American countries where $R \& D$ and gross fixed capital formation does not influence real output significantly. The findings of this study align with previous studies (such as Estrada and Montero [14], Pessoa [11], Kim [15], Bravo-Ortega and Marin, [19]; and Goschin, [22]) but contradict others (such as Sylwester, [7] and Samimi and Alerasone, [20]). The reason why this study contradicts Sylwester [6] and Samimi and Alerasone [20] may be because of the wrong methodological approach of not considering potential endogeniety problem. In estimation relationship between R\&D and economic growth, endogeniety is an important issue to consider and ignoring it may have undesired consequences. That is, low level of growth may influence low investment in R\&D. Similarly, a country with low level of investment in R\&D is expected to exhibit slow growth.

In terms of policy, African needs to harness its endowed resources to generate higher economic performance. This will help to adequately invest in $R \& D$ sector. Besides, the weak response of output to $\mathrm{R} \& \mathrm{D}$ implies that more $\mathrm{R} \& \mathrm{D}$ investment is needed to achieve the desired economic growth in Africa. One of the ways of going about this is to encourage and provide adequate funding for basic (aimed at improving scientific theories for improved understanding of natural or other phenomena) and industrial research (aimed at the acquisition of new knowledge and skills for improving and developing new 
products, processes or services) as well as further training of personnel involved in $R \& D$ activities. In other countries regions such as Asia and OECD, the response of RGDP to R\&D expenditure is larger than what obtains in Africa and this can be attributed to the huge investment in $R \& D$. In addition, there is need to mobilize domestic resources through domestic savings and investment. This will go a long way to generate higher stability of the region and engage its teeming unemployed resources. This is becoming relevant since resources mobilized domestically are more reliable and have potential of generating desired decent jobs than externally mobilized resources.

\section{References}

1. N.L. Stokey, "R\&D and economic growth," The Review of Economic Studies, vol. 62, no. 3, pp. 469-489, 1995.

2. World Bank (2015). World Development Indicators.

3. K.B. Clark and Z. Griliches, "Productivity growth and R\&D at the business Level: Results from the PIMS data base," NBER WORKING PAPER SERIES 916, 1984. Available: http://www.nber.org/papers/w0916.pdf

4. Y. Kim, 'R\&D investment and productivity: A comparative study of Japanese and Korean firms', RIETI Discussion Paper 13-E-043, 2013. Available: http://www.rieti.go.jp/jp/publications/dp/13e043.pdf

5. I. Otani, and D. Villanueva, "Long-term growth in developing countries and its determinants: an empirical analysis," World Development, vol. 18, no. 6, pp. 769-783, 1990.

6. D. Romer, "Advanced macroeconomics". Third Edition. McGraw-Hill/Irwin Companies, Inc., New York, 2006.

7. K. Sylvester, "R\&D and economic growth," Knowledge, Technology \& policy, vol. 13, no. 4, pp. 71-84, 2001.

8. D. Guellec and P.B. de la Potterie, "R\&D and productivity growth: Panel data analysis of 16 OECD countries," OECD Economic Studies, vol. 33, pp. 103-126, 2001. Available: http://www.oecd.org/eco/growth/1958639.pdf

9. H. Ulku, "R\&D, innovation, and economic growth: an empirical analysis," IMF working paper /04/185, 2004.

10.M. Falk, "R\&D spending in the high-tech sector and economic growth," Research in Economics, vol. 61, pp. 140$147,2007$.

11.A. Pessoa,"R\&D and economic growth: how strong is the Link?" Economic Letters vol. 107, no. 2, pp. 152-154, 2010 .

12.E. Gumus and F. Celikay, "R\&D expenditure and Economic growth: New empirical evidence," The Journal of Applied Economic Research, vol. 9, no. 3, pp. 205-217, 2015.

13.R.K Goel, E.J. Payne and R. Ram, "R\&D expenditures and U.S. economic growth: A disaggregated approach," Journal of Policy Modeling, vol. 30, no. 2, pp. 237-250, 2008.

14.Á. Estrada and J.M. Montero, "R\&D investment and endogenous growth: a SVAR approach," Documentos de Trabajo 0925, 2009. Available: http://papers.ssrn.com/sol3/papers.cfm?abstract_id=1494899

15.J.W. Kim, "The economic growth effect of R\&D activity in Korea," Korea and the World Economy, vol. 12, no. 1, pp. 25-44, 2011.

16.Z. Křístková, "Impact of R\&D investment on economic growth of the Czech Republic - A recursively dynamic CGE approach," Prague Economic Papers, vol. 4, pp. 412-433, 2012.

17.J.F. Santosa and M. Catalao-Lopes, "R\&D matter for economic growth or vice-versa? An application to Portugal and other European Countries," Archives of Business Research, vol. 2, no. 3, pp. 1-17, 2014.

18.C. Bozkurt, "R\&D expenditures and economic growth relationship in Turkey," International Journal of Economics and Financial Issues, vol. 5, no. 1, pp. 188-198, 2015.

19.C. Bravo-Ortega and Á.G. Marin, "R\&D and productivity: A two way avenue?" World Development, vol. 39, no. 7, pp. 1090-1107, 2011.

20.A.J. Samimi, and S.M. Alerasoul, "R\&D and economic growth: New evidence from some developing countries," Australian Journal of Basic and Applied Sciences vol.3, no. 4, pp. 3464-3469, 2009.

21.I. Love and L. Ziccino, "Financial development and dynamic investment behaviour: Evidence from panel VAR," Quarterly Review of Economics and Finance, vol. 46, pp. 190-210, 2006.

22.Z. Goschin, "R\&D as an engine of regional economic growth in Romania," International Study on Regional Science, vol. 8, no. 1, pp. 24-37, 2014.

23.A. Kokko, G.P. Tingvall and J. Videnord, "The growth effects of R\&D spending in the EU: A meta-analysis," Economic open assess Discussion Paper 2015-29, 2015. Available: http://www.economics-ejournal.org/ economics/discussionpapers/2015-29 


\section{Appendix:}

Table A1. Summary of empirical previous empirical studies

\begin{tabular}{|c|c|c|c|c|c|c|}
\hline $\begin{array}{l}\text { Author(s)/ } \\
\text { Year } \\
\end{array}$ & Objectives & $\begin{array}{l}\text { Scope } \\
\text { country } \\
\end{array}$ & \begin{tabular}{|l} 
Variables \\
Considered \\
\end{tabular} & $\begin{array}{l}\text { Theoretical } \\
\text { framework }\end{array}$ & Methodology & Basic Findings \\
\hline $\begin{array}{l}\text { Sylwester } \\
{[7]}\end{array}$ & $\begin{array}{l}\text { To examine the } \\
\text { association } \\
\text { between } R \& D \\
\text { and the growth } \\
\text { rate of output per } \\
\text { capita }\end{array}$ & $\begin{array}{l}20 \text { OECD } \\
\text { countries }\end{array}$ & $\begin{array}{l}\text { various } \mathrm{R} \& \mathrm{D} \\
\text { expenditures and } \\
\text { growth rate of GDP } \\
\text { per capita }\end{array}$ & $\begin{array}{l}\text { New growth } \\
\text { theory }\end{array}$ & $\begin{array}{l}\text { multivariate } \\
\text { regression } \\
\text { technique }\end{array}$ & $\begin{array}{l}\text { There is no strong } \\
\text { association between R\&D } \\
\text { and economic growth. But } \\
\text { when considering only G-7 } \\
\text { countries, there is a positive } \\
\text { association. }\end{array}$ \\
\hline $\begin{array}{l}\text { Guellec and } \\
\text { he de la } \\
\text { Potterie [8] }\end{array}$ & $\begin{array}{l}\text { To analyse the } \\
\text { contribution of } \\
\text { technical change } \\
\text { to Total factor } \\
\text { productivity of } \\
\text { industry (MFP) } \\
\text { growth } \\
\end{array}$ & $\begin{array}{l}16 \text { OECD } \\
\text { countries; } \\
1980-98\end{array}$ & $\begin{array}{l}\text { MPF growth, R\&D } \\
\text { capital stock } \\
\text { (Business, public } \\
\text { and foreign) }\end{array}$ & $\begin{array}{l}\text { Simple Cobb- } \\
\text { Douglas } \\
\text { production } \\
\text { function. }\end{array}$ & $\begin{array}{l}\text { Error correction } \\
\text { model }(\mathrm{ECM})\end{array}$ & $\begin{array}{l}\text { Technology is relevant to } \\
\text { economic growth. }\end{array}$ \\
\hline Ulku [9] & $\begin{array}{l}\text { To investigate the } \\
\text { relationship } \\
\text { between } \mathrm{R} \& \mathrm{D} \\
\text { and growth }\end{array}$ & $\begin{array}{l}20 \text { OECD } \\
\text { and } 10 \text { Non- } \\
\text { OECD } \\
\text { countries; } \\
1981-97\end{array}$ & $\begin{array}{l}\text { Per capita GDP, } \\
\text { gross } R \& D \\
\text { expenditure, total } \\
\text { factor productivity } \\
\text { (TFP) and patents }\end{array}$ & $\begin{array}{l}\text { R\&D based } \\
\text { growth model } \\
\text { of Romer } \\
(1990)\end{array}$ & $\begin{array}{l}\text { Generalized } \\
\text { method of } \\
\text { moment (GMM) } \\
\text { Panel data } \\
\text { techniques }\end{array}$ & $\begin{array}{l}\text { Positive relationship between } \\
\text { per capita GDP and } \\
\text { innovation in both OECD } \\
\text { and non-OECD countries, } \\
\text { while the effect of R\&D } \\
\text { stock on innovation is } \\
\text { significant only in the OECD } \\
\text { countries with large markets. }\end{array}$ \\
\hline Falk [10] & $\begin{array}{l}\text { To estimate the } \\
\text { impact of } \\
\text { investment in } \\
\text { R\&D on long- } \\
\text { term economic } \\
\text { growth }\end{array}$ & $\begin{array}{l}\text { OECD } \\
\text { countries; } \\
1970 \text { to } \\
2004 .\end{array}$ & $\begin{array}{l}\text { R\&D expenditure, } \\
\text { share of } R \& D \\
\text { investment in the } \\
\text { high-tech sector, } \\
\text { GDP per capita and } \\
\text { GDP per hour } \\
\text { worked }\end{array}$ & $\begin{array}{l}\text { Augmented } \\
\text { Solow growth } \\
\text { model }\end{array}$ & $\begin{array}{l}\text { System GMM } \\
\text { estimator }\end{array}$ & $\begin{array}{l}\text { R\&D investment in the high- } \\
\text { tech sector has strong } \\
\text { positive effects on GDP per } \\
\text { capita and GDP per hour } \\
\text { worked in the long term. }\end{array}$ \\
\hline $\begin{array}{l}\text { Goel, Payne } \\
\text { and Ram } \\
{[13]}\end{array}$ & $\begin{array}{l}\text { To investigate } \\
\text { R\&D-growth } \\
\text { relationship }\end{array}$ & $\begin{array}{l}\text { U.S; } 1953- \\
2000\end{array}$ & $\begin{array}{l}\text { R\&D expenditure } \\
\text { (federal, non federal, } \\
\text { defense, non- } \\
\text { defense) and GDP } \\
\text { growth }\end{array}$ & $\begin{array}{l}\text { New growth } \\
\text { theory }\end{array}$ & $\begin{array}{l}\text { Bounds testing } \\
\text { approach }\end{array}$ & $\begin{array}{l}\text { Larger role of federal R\&D } \\
\text { relative to non-federal R\&D } \\
\text { in growth, and a stronger } \\
\text { role of defense R\&D than of } \\
\text { non-defense (federal) R\&D }\end{array}$ \\
\hline $\begin{array}{l}\text { Samimi and } \\
\text { Alerasoul, } \\
{[20]}\end{array}$ & $\begin{array}{l}\text { To estimate the } \\
\text { impact of R\&D } \\
\text { on economic } \\
\text { growth. }\end{array}$ & $\begin{array}{l}30 \\
\text { developing } \\
\text { countries: } \\
2000-2006\end{array}$ & $\begin{array}{l}\text { R\&D expenditure } \\
\text { (\% of GDP); } \\
\text { researchers in each } \\
\text { one million } \\
\text { population; scientific } \\
\text { output, GDP, } \\
\text { Investment (GFCF) } \\
\text { and labour force } \\
\end{array}$ & $\begin{array}{l}\text { New growth } \\
\text { Theory }\end{array}$ & $\begin{array}{l}\text { Panel data } \\
\text { regression }\end{array}$ & $\begin{array}{l}\text { No significance positive } \\
\text { impact of R\&D }\end{array}$ \\
\hline $\begin{array}{l}\text { Estrada and } \\
\text { Montero } \\
{[14]}\end{array}$ & $\begin{array}{l}\text { To analyze the } \\
\text { impact of } R \& D \\
\text { investment on } \\
\text { long run growth }\end{array}$ & $\begin{array}{l}\text { six } \\
\text { developed } \\
\text { economies } \\
\text { plus Spain: } \\
\text { 1970-2006 }\end{array}$ & $\begin{array}{l}\text { GDP growth, } \\
\text { inflation and R\&D } \\
\text { investment }\end{array}$ & $\begin{array}{l}\text { Endogenous } \\
\text { growth model }\end{array}$ & $\begin{array}{l}\text { structural vector } \\
\text { autoregressive } \\
\text { (SVAR) model }\end{array}$ & $\begin{array}{l}\text { R\&D shocks have a positive } \\
\text { impact on economic activity, } \\
\text { but a heterogeneous effect on } \\
\text { prices. }\end{array}$ \\
\hline
\end{tabular}




\begin{tabular}{|c|c|c|c|c|c|c|}
\hline Pessoa [11] & $\begin{array}{l}\text { To examine the } \\
\text { relationship } \\
\text { between R\&D } \\
\text { outlays and } \\
\text { economic growth }\end{array}$ & $\begin{array}{l}28 \text { OECD; } \\
1995-2005\end{array}$ & $\begin{array}{l}\text { GDP and BERD as } \\
\text { a } \% \text { of industrial } \\
\text { product }\end{array}$ & $\begin{array}{l}\text { Ideas-driven } \\
\text { growth } \\
\text { Mode with } \\
\text { free entry and } \\
\text { exit } \\
\text { conditions } \\
\end{array}$ & $\begin{array}{l}\text { Fitted regression } \\
\text { model }\end{array}$ & $\begin{array}{l}\text { Weak impact of innovation } \\
\text { policy on aggregate } \\
\text { productivity. Only } \\
\text { Increased in R\&D intensity } \\
\text { improves growth }\end{array}$ \\
\hline $\operatorname{Kim}[15]$ & $\begin{array}{l}\text { To investigate the } \\
\text { contribution } \\
\text { effect of R\&D } \\
\text { stock to economic } \\
\text { growth } \\
\end{array}$ & $\begin{array}{l}\text { Korea: } 1976- \\
2009\end{array}$ & $\begin{array}{l}\text { GDP growth, labor, } \\
\text { capital, public and } \\
\text { private R\&D stocks }\end{array}$ & $\begin{array}{l}\text { R\&D based } \\
\text { Cobb-Douglas } \\
\text { production } \\
\text { function }\end{array}$ & $\begin{array}{l}\text { Cointegration } \\
\text { analysis }\end{array}$ & $\begin{array}{l}\text { public and private } \mathrm{R} \& \mathrm{D} \\
\text { stocks account for economic } \\
\text { growth of about } 16 \% \text { and } \\
19 \% \text {, respectively }\end{array}$ \\
\hline $\begin{array}{l}\text { Bravo- } \\
\text { Ortega and } \\
\text { Marin [19] }\end{array}$ & $\begin{array}{l}\text { To study the } \\
\text { relationship } \\
\text { between R\&D } \\
\text { and productivity } \\
\end{array}$ & $\begin{array}{l}65 \text { countries; } \\
1965-2005\end{array}$ & $\begin{array}{l}\text { Percapita R\&D } \\
\text { expenditure, social } \\
\text { returns to R\&D } \\
\text { spending and TFP }\end{array}$ & $\begin{array}{l}\text { New growth } \\
\text { theory }\end{array}$ & IV panel data & $\begin{array}{l}\text { increase in R\&D per } \\
\text { capita generates increase in } \\
\text { TFP in the long-run }\end{array}$ \\
\hline $\begin{array}{l}\text { Křístková } \\
{[16]}\end{array}$ & $\begin{array}{l}\text { To quantify the } \\
\text { impact of R\&D } \\
\text { activity on the } \\
\text { long-term } \\
\text { economic growth }\end{array}$ & $\begin{array}{l}\text { Czech } \\
\text { Republic, } \\
\text { 2000-2009 }\end{array}$ & $\begin{array}{l}\text { R\&D expenditure, } \\
\text { Physical investment } \\
\text { and GDP. }\end{array}$ & $\begin{array}{l}\text { New growth } \\
\text { theory }\end{array}$ & $\begin{array}{l}\text { CGE model with } \\
\text { R\&D investment } \\
\text { and knowledge } \\
\text { accumulation }\end{array}$ & $\begin{array}{l}\text { Knowledge accumulation } \\
\text { contributes to higher } \\
\text { economic growth and } \\
\text { investment in capital goods } \\
\text { is more efficient in achieving } \\
\text { higher economic growth }\end{array}$ \\
\hline $\begin{array}{l}\text { Santosa and } \\
\text { Catalao- } \\
\text { Lopes }[17]\end{array}$ & $\begin{array}{l}\text { To investigate the } \\
\text { causal } \\
\text { relationship } \\
\text { linking R\&D and } \\
\text { growth }\end{array}$ & $\begin{array}{l}\text { European } \\
\text { Union (EU) } \\
\text { countries; } \\
\text { 1987-2008 }\end{array}$ & $\begin{array}{l}\text { GDP and industrial } \\
\text { R\&D expenditure }\end{array}$ & $\begin{array}{l}\text { New growth } \\
\text { theory }\end{array}$ & $\begin{array}{l}\text { Cointegrtation } \\
\text { and Granger } \\
\text { causality test }\end{array}$ & $\begin{array}{l}\text { A causal relationship from } \\
\text { growth to R\&D can only be } \\
\text { proven for France and Spain, } \\
\text { whereas the inverse causality } \\
\text { only seems to exist for The } \\
\text { Netherlands. }\end{array}$ \\
\hline Goschin [22] & $\begin{array}{l}\text { To explore the } \\
\text { role of R\&D on } \\
\text { production factors }\end{array}$ & $\begin{array}{l}\text { Romania: } \\
\text { 1995-2010 }\end{array}$ & $\begin{array}{l}\text { GDP per capita, } \\
\text { R\&D expenditure, } \\
\text { labour and GFCF }\end{array}$ & $\begin{array}{l}\text { New growth } \\
\text { theory }\end{array}$ & $\begin{array}{l}\text { Fixed and } \\
\text { random effects } \\
\text { Panel data }\end{array}$ & $\begin{array}{l}\text { Significant impact of } \mathrm{R} \& \mathrm{D} \\
\text { expenditures on the regional } \\
\text { economic growth process in } \\
\text { Romania }\end{array}$ \\
\hline $\begin{array}{l}\text { Kokko, } \\
\text { Tingvall, } \\
\text { and } \\
\text { Videnord } \\
{[23]}\end{array}$ & $\begin{array}{l}\text { To examine the } \\
\text { link between } \\
\text { R\&D spending } \\
\text { and economic } \\
\text { growth }\end{array}$ & $\begin{array}{l}49 \text { countries } \\
\text { including } \\
\text { EU and } \\
\text { United } \\
\text { States. }\end{array}$ & $\begin{array}{l}\text { GDP, R\&D } \\
\text { spending (aggregate } \\
\text { and industrial), } \\
\text { Human capital, } \\
\text { population growth }\end{array}$ & $\begin{array}{l}\text { New growth } \\
\text { theory }\end{array}$ & $\begin{array}{l}\text { Meta regression } \\
\text { models }\end{array}$ & $\begin{array}{l}\text { The results suggest that the } \\
\text { growth-enhancing effect of } \\
\text { R\&D in the EU15 countries } \\
\text { does not differ from that in } \\
\text { other countries in general, } \\
\text { but it is less significant than } \\
\text { other industrialized } \\
\text { countries. }\end{array}$ \\
\hline Bozkurt [18] & $\begin{array}{l}\text { To investigate the } \\
\text { long-run } \\
\text { relationship } \\
\text { between R\&D } \\
\text { expenditure and } \\
\text { economic growth }\end{array}$ & $\begin{array}{l}\text { Turkey; } \\
1996-2013\end{array}$ & $\begin{array}{l}\text { R\&D expenditure } \\
\text { and GDP per capita }\end{array}$ & $\begin{array}{l}\text { New growth } \\
\text { theory }\end{array}$ & $\begin{array}{l}\text { Johansen co- } \\
\text { integration and } \\
\text { the vector error } \\
\text { correction models }\end{array}$ & $\begin{array}{l}\text { The growth rate of GDP will } \\
\text { increase by } 0.3 \% \text { if R\&D } \\
\text { shares in the GDP increases } \\
1 \% \text {. }\end{array}$ \\
\hline
\end{tabular}

Source: Author's Compilation

Table A2. List of countries sampled for the study

\begin{tabular}{l|l|l|l|l}
\hline $\boldsymbol{S} / \boldsymbol{N}$ & Africa & OECD & Asia & South America \\
\hline 1 & Algeria & Canada & China & Argentina \\
\hline 2 & Benin & Denmark & India & Brazil \\
\hline 3 & Botswana & Finland & Indonesia & Trinidad and Tobago \\
\hline
\end{tabular}




\begin{tabular}{l|l|l|l|l}
\hline 4 & Burkina Faso & France & Malaysia & Venezuela, RB \\
\hline 5 & Burundi & Germany & Thailand & \\
\hline 6 & Cameroon & Hungary & & \\
\hline 7 & Central African Republic & Ireland & & \\
\hline 8 & Egypt, Arab Rep. & Japan & & \\
\hline 9 & Gabon & Korea, Rep. & & \\
\hline 10 & Kenya & Netherlands & & \\
\hline 11 & Madagascar & Norway & & \\
\hline 12 & Mali & Spain & & \\
\hline 13 & Mauritius & Sweden & & \\
\hline 14 & Mozambique & Turkey & & \\
\hline 15 & Nigeria & United Kingdom & & \\
\hline 16 & Rwanda & United States & & \\
\hline 17 & Senegal & & & \\
\hline 18 & South Africa & & & \\
\hline 19 & Sudan & & & \\
\hline 20 & Tanzania & & & \\
\hline 21 & Togo & & & \\
\hline 22 & Tunisia & & & \\
\hline 23 & Uganda & & & \\
\hline & & & & \\
\hline
\end{tabular}

Source: Author's Compilation 